Chirurgia (2019) 114: 487-493

No. 4, July - August

Copyright@ Celsius

http://dx.doi.org/10.21614/chirurgia.114.4.487

\title{
When is Laparoscopy Avoided in the Treatment of Surgical Complications due to Crohn Disease
}

\author{
Iulian Slavu', Cornelia Nitipir², Lucian Alecư ${ }^{3}$ Adrian Tulin³ , Silviu Constantinoiu ${ }^{4}$ \\ ${ }^{1}$ General Surgery Clinic, Emergency Clinical Hospital, Bucharest, Romania \\ ${ }^{2}$ Emergency Clinical Hospital, Elias, Bucharest, Romania \\ ${ }^{3}$ General Surgery Clinic, Emergency Clinical Hospital, Agrippa Ionescu, Bucharest, Romania \\ ${ }^{4}$ Center of Excelence of Esophageal Cancer, Sfanta Maria, Bucharest, Romania
}

Corresponding author:

Alecu Lucian, MD

General Surgery Clinic

Emergency Clinical Hospital

Agrippa lonescu", Bucharest Romania

E-mail: Lucianalecu@yahoo.com

\section{Rezumat \\ Când este laparoscopia evitată în cadrul tratamentului chirurgical al complicatiilor bolii Crohn}

Introducere: Boala Crohn (BC) a înregistrat o creştere constantă a incidenței pe parcursul anilor în România. În momentul de față, laparoscopia cunoaşte o evoluție lentă în a fi selectată drept o opțiune terapeutică fezabilă pentru pacienții cu BC.

Material şi metodă: Studiul este retrospectiv. Perioada în care s-au adunat datele s-a răspândit pe decursul a 8 ani (01.01.201101.01.2019). Datele au fost preluate de la trei Spitale Clinice din Bucureşti, România.

Rezultate: diagnosticul preoperator al unei fistule intestinale ( $p=0,02)$, sepsisul $(p=0,01)$ sau vârsta înaintată trebuie privite ca o limită a abordului laparoscopic în cazul complicațiilor BC. De asemenea, în situațiile de urgență, abordul deschis ar trebui să fie tratamentul optim chirurgical $(p=0,001)$.

Concluzie: Laparoscopia este o opțiune chirurgicală fezabilă în tratamentul complicatiilor chirurgicale ce aparțin BC. Pentru a spori siguranța intervenției, este importantă alegerea corectă a pacienților pentru această tehnică.

Cuvinte cheie: laparoscopie, boala Crohn, chirurgie

Abstract

Introduction: Crohn disease (CD) has seen a steady increase in 
incidence over the years in Romania. Laparoscopy had a slow evolution as a feasible therapeutic option for patients with CD.

Material and Method: The study is retrospective. The period on which the data was gathered spread over 8 years (01.01.2011-01.01.2019). Data was retrieved from three Clinical Hospitals in Bucharest, Romania.

Results: the preoperative diagnosis of an intestinal fistula $(p=0,02)$, sepsis $(p=0.01)$ or increased age should be regarded as a limitation for a laparoscopic approach in CD complications. Also in emergency settings an open approach should be the mainstay treatment (approach $p=0.001$ ).

Conclusion: Laparoscopy is a feasible surgical option in the treatment of surgical complication in CD. In order to increase the safety of the intervention, correct selection of patients is important.

Key words: laparoscopy, Crohn, surgery

\section{Introduction}

Crohn disease (CD) is a chronic inflammatory pathology that affects the entire digestive tract. The inflammation has a transmural character that involves the entire thickness of the intestinal wall (1). Despite the progress in the medical treatment of CD, there is still an increased risk of a surgical intervention (2).

Taking into account the high reintervention risk along with the young age at which these patients are diagnosed and increased life expectancy - both variables make this subpopulation ideal for laparoscopic surgery. However, laparoscopy has seen a slow evolution as a feasible therapeutic option for these patients. General surgery, usually is at first selective with new therapies for example as it was with total mesorectal excision in rectal cancer in 1982. This technique has become nowadays the standard of care in rectal cancer (3).

Technical difficulties due to the presence of abdominal inflammatory tumor masses or intestinal fistulas and visceral adhesions have limited the use of laparoscopy in complex resections in CD.

Also, inflammation associated with the mesentery makes it difficult to dissect and resect. Another drawback is due to the fact that in laparoscopy tactile feedback is lost thus the surgeon can overlook areas of transmural inflammation with luminal obliteration which do not have a macroscopic signature.

All these risk factors recommend that laparoscopic surgery in CD is practiced by a experienced surgeon in laparoscopy who can also manage complications through an open approach.

Guidelines currently are not in support of imposing this surgical technique by limiting it or even contraindicating laparoscopic intestinal resections as the first line of treatment in CD due to insufficient data in the literature, especially from large prospective studies.

Despite these apparent limitations, surgical treatment through a minimally invasive approach has increased each year. Multiple studies demonstrated the efficacy and safety of these surgeries. Rosman AS et al. compared laparoscopic surgery with open approach in the treatment of CD complications demonstrated that minimally invasive procedure were safe and feasible (4).

The objective of our study was to verify if intestinal fistula, sepsis, age (over 50 years) and emergency surgery can be considered limitations of laparoscopic surgery in CD in order to correctly identify patients who are candidates to a minimally invasive procedure.

\section{Material and Methods}

The study is retrospective. The period on which the data was gathered spread over 8 
years (01.01.2011-01.01.2019). Data was retrieved from three Clinical Hospitals in Bucharest, Romania. The following variables were obtained: age, sex, comorbidities, the context of surgery (elective/emergency), surgical indication, preoperative medication for CD, postoperative remission, type of approach (laparoscopy/open),

A number of 62 patients underwent surgery for CD complications. This subgroup was subsequently differentiated according to the approach used in: laparoscopic subgroup and an open-access subgroup.

The data obtained from the study protocols was processed using IBM SPSS software version 20.0. The two subgroups of interest were compared using Chi-Square test for the presence or absence of preoperative treatment, surgical indication(intestinal obstruction) and sepsis and Fisher's Exact test for the context of surgical intervention (defined as elective or urgent), intestinal fistula, abdominal abscess, suspicion of BC, other causes, intestinal perforation and maximum medical therapy.The postoperative outcome, defined as remission or active disease was compared with Fisher's Exact Test. For the mean age comparison between the two subgroups the T-test was used. For all comparisons, the probability of an error less than $5 \%(p<0.05)$ was considered the statistical significance threshold.

\section{Inclusion Criteria}

Diagnosis of CD and at least one surgical intervention due to CD complications.

\section{Ethics}

The retrospective analysis of the data has been approved by an Ethics Committee of the institution within which the work was undertaken and it conforms to the provisions of the Declaration of Helsinki.

\section{Results}

We identified a number of 62 patients operated for complications of CD. From the initial group, we observed that a number of 13 patients were operated with the help of laparoscopy.

Mean age of the laparoscopy group was: $42.06 \pm 14.50$ years vs $34.23 \pm 11.28$ years for the open approach, $\mathrm{p}=0.07$ (T-test).

The vast majority of patients operated by a minimally invasive approach received medical treatment for CD in the preoperative period. A statistically significant component with a of $p<0.001$ of the open-approach group did not receive medical treatment $\mathrm{n}=34 / 49(69.4 \%)$.

The most frequent indication for surgery was intestinal obstruction in both subgroups of patients: open approach $\mathrm{n}=28 / 49$ (57\%) and laparoscopy $\mathrm{n}=11 / 13(85 \%)(\mathrm{p}=0.106$, Chi-Square test) (Figs. 1, 2). The following preoperative diagnostics were without statistical significance: abdominal abscess ( $p=0.099$, Fisher's Exact Test), suspicion of CD $(p=1.000$, Fisher's Exact Test $)$, other indications $\mathrm{p}=0.378$, Fisher's Exact Test), intestinal perforation $(\mathrm{p}=0.327$, Fisher's Exact Test). It is worth mentioning that when there was suspicion or diagnosis of an
Figure 1. Open approach: surgical indication

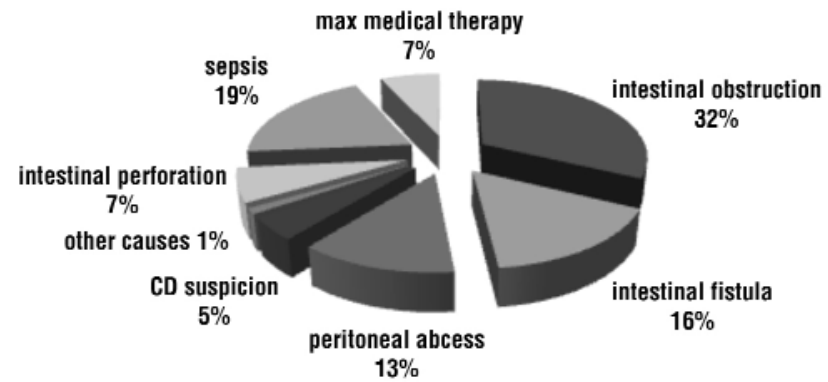


Figure 2. Minimally invasive approach: surgical indication

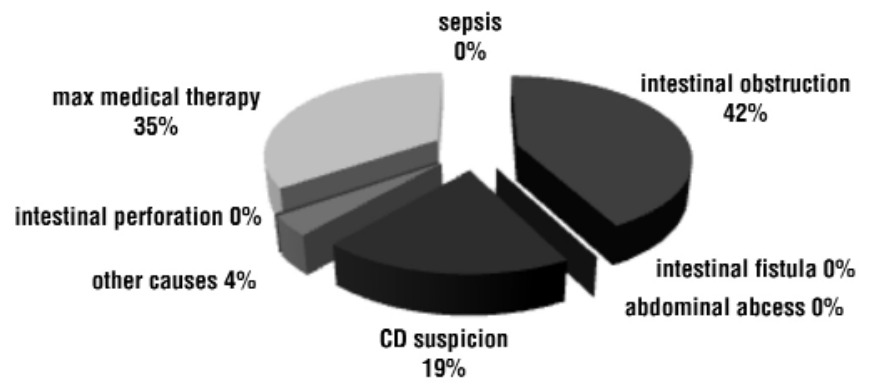

intestinal fistula, open approach consisted the mainstay surgical treatment when compared to laparoscopy - significant results $(p=0.02$, Fisher's Exact Test). This was also the case when the patient was diagnosed with sepsis ( $\mathrm{p}=0.01$, Chi-Square Test) (Figs. 1, 2).

We observed that laparoscopy was preferred mostly in patients with a lack of response to medical treatment when compared to an open approach, statistically significant results ( $\mathrm{p}<0.001$, Fisher's Exact Test) (Figs. 1, 2) .

When the two subgroups were compared with regards to emergency situations it was observed that elective interventions were performed by laparoscopic approach in $92.3 \%$ cases $(p<0.001$, Fisher's Exact Test) while in emergency situations the laparoscopic approach was avoided.

Patients operated with a minimally invasive approach entered more frequently in remission after surgery $\mathrm{n}=8 / 13(62 \%) \mathrm{VS}$ open approach $\mathrm{n}=12 / 49(25 \%)(\mathrm{p}=0.01$, Fisher's Exact Test $)$.

The rate of perioperative complications did not show statistically significant variations between open and laparoscopic approach $(\mathrm{p}=0.378$, Fisher's Exact Test).

\section{Discussion}

Patients with CD are frequently young at diagnosis and can benefit fully from the advantages of an minimally invasive approach such as: reduced length of hospital stay, better aesthetic appearance, faster social reintegration. Eshuis et al. have demonstrated on a group of 69 patients operated for complications of CD which were separated into two groups: open and laparoscopic that there were no differences in the quality of postoperative life, but the cosmetic impact was clearly superior in favor of the laparoscopy group - $p<0.001$ (5).

Any procedure that reduces the rate of surgical complications in this category of patients which has a 50\% reintervention risk at 10 years is welcomed $(6,7)$.

The safety of minimally invasive approaches to CD surgery was also evaluated by Umanskiy et al. in 2010, Soop et al. in 2009 as well as Kroesen et al. in 2009 and all demonstrated the effectiveness of this approach (8-10).

By dividing the group of patients operated for complications of CD into two-arms it was observed that the mean age of the patients operated via an open approach was higher than the age of patients operated laparoscopically. Although according to literature elderly patients $>50$ years have a mild evolution of the disease and associate multiple cardiovascular and pulmonary comorbidities which are inherent to advanced age. In laparoscopy, operative time is increased when compared to open surgery from 30 minutes to 150 minutes $(11,12)$. In these cases, prolonged pneumoperitoneum and general anesthesia significantly influence postoperative morbidity.

Data was also confirmed by Sunil V Patel et al. in a meta-analysis published in 2013 on 3,000 patients operated for complications of $\mathrm{CD}$, in which he also observed that patients operated laparoscopically tended to be younger (13).

Due to the high risk of reintervention - the correct identification of patients for laparoscopic surgery is of utmost importance and in 
these situations preoperative investigations are can enhance the success and safety of the intervention to laparoscopy tends to be avoided in situations which require emergency surgical interventions.

We also observed that patients who did not respond to maximum medical therapy were more frequently selected for laparoscopic interventions than the open arm $(p<0.001)$.

An intestinal fistula is one of the most feared complications of CD - and its presence implies the existence of an intense abdominal adherence syndrome that probably associates an inflammatory mass in a patient with an aggressive form of $\mathrm{CD}$ unresponsive to medical therapy or undiagnosed. In these cases, surgical interventions are complex and frequently involve resection of the perforated intestinal segment with anastomosis or stomy in a complex surgical intervention (14). If an intestinal fistula is diagnosed intraoperative during a minimally invasive procedure, this should be indicative for conversion to open surgery as Regan et. al, and C. Max Schmidt et. al recommend $(15,16)$. European treatment guidelines for CD do not recommend laparoscopic approach in complex cases which involve multi-visceral resections (17).

In the study published by Goyer $\mathrm{P}$ et al. in 2009 when he evaluated comparatively two groups of patients with complex or simple interventions without extensive dissection or multi-visceral resection - he did not identify statistically significant changes in the postoperative period of the patients but the operative time, the frequency of stoma creation and the conversion rate were more frequently encountered in the group which required complex surgical interventions (18). In our group we observed that when intestinal fistulas were diagnosed the elective treatment was realized via open approach thus confirming the recommendations of the guidelines and literature. The results were statistically significant $p=0.02$.

In the cases where a septic syndrome is diagnosed, a laparoscopic approach is an option that requires further investigation into its feasibility - since it does not allow good lavage and drainage of the entire peritoneal cavity or an effective exploration to identify the source of sepsis. Operating time in a septic patient should also be shortened as much as possible to avoid the triad: acidosis, hypothermia and clotting disorder, and as mentioned earlier in the article this time may be prolonged with as much as 150 minutes when compared to the open approach. In the studied group - in sepsis, the majority of the patients were operated via an open approach statistically significant results $\mathrm{p}<0.001$.

The optimal use of laparoscopic surgery in CD patients seems to be in elective situations as it tends to be avoided in emergency settings. Data regarding the use of laparoscopy in the treatment of CD complications in emergency settings is limited and the safety of these interventions lack supporting data. In our group, laparoscopic interventions were performed mainly under elective conditions $(92.3 \%, \mathrm{p}<0.001)$ while the open approach was used mostly for emergency situations. The correct selection of patients is of utmost importance to ensure the safety of these procedures.

The incidence of perioperative complications did not vary significantly between the two groups (open approach versus laparoscopic approach, $p=0.037$ ). This rate of perioperative complications at least similar to open surgery was also confirmed by Cary B et al; Sergio Casillas et. al; Ivan Kristo et. al; Hermann Kessler et. al; Stavros A. Antoniou et. al while Sunil V Patel et al. in its meta-analysis identified a reduction in perioperative complications in the laparoscopic approach (19-25). This observation is important as it eases the fears that portions of digestive tract affected by CD are overlooked when minimally invasive procedures are used as they lack tactile feedback.

The laparosocopy group seemed to enter more frequently in remission after surgery but it has to be metioned that the vast majority of patients in the laparoscopic arm had a milder form of the disease than the open surgery arm, which may be one of the explanations of the higher incidence of postoperative remission induction. On the other hand, the trauma due to the lack of large incisions is reduced and 
this in turn translates in a diminished inflammatory response.

\section{Study Limits}

The study presented has the limits of a retrospective study. It was difficult to appreciate the evolution of the disease until the surgical intervention. We could not follow-up, in the long run, the effectiveness of the surgical procedure.

\section{Conclusion}

In conclusion, the preoperative diagnosis of an intestinal fistula, sepsis or increased age should be regarded as a limitation for a laparoscopic approach in CD complications. Also in emergency settings an open approach should be the mainstay treatment.

\section{Author's Contributions}

Conception and design: Silviu Constantinoiu, Tulin Adrian, Alecu Lucian, Nitipir Cornelia. Administrative support: Silviu Constantinoiu, Tulin Adrian, Alecu Lucian. Provision of study material or patients: Silviu Constantinoiu, Tulin Adrian, Alecu Lucian. Collection and assembly of data: Slavu Iulian, Nitipir Cornelia. Data analysis and interpretation: Slavu Iulian, Nitipir Cornelia. Manuscript writing: Slavu Iulian. Final approval of manuscript: Silviu Constantinoiu, Tulin Adrian, Alecu Lucian.

\section{Funding}

No funding was required for this study.

\section{Conflict of Interest}

The authors declare no conflicts of interests.

\section{References}

1. Bandzar S, Gupta S, Platt MO. Crohn's disease: a review of treatment options and current research. Cell Immunol. 2013; 286(1-2):45-52

2. Bernell 0 , Lapidus $A$, Hellers $G$. Risk factors for surgery and recurrence in 907 patients with primary ileocaecal Crohn's disease. Br J Surg. 2000:87(12):1697-701.

3. Ion D, Stoian RV, Paduraru DN, Bolocan A, Serban M. Certitudes and controversy regarding neural elements preservation in total mesorectal excision technique. Chirurgia (Bucur). 2012;107(2): 231-6. Romanian

4. Rosman AS, Melis M, Fichera A. Meta-analysis of trials comparing laparoscopic and open surgery for Crohn's disease. Surg Endosc. 2005;19(12):1549-55

5. Eshuis EJ, Slors JF, Stokkers PC, Sprangers MA, Ubbink DT, Cuesta MA et al. Long-term outcomes following laparoscopically assisted versus open ileocolic resection for Crohn's disease. Br J Surg. 2010;97(4):563-8.

6. Spinelli A, Sacchi M, Bazzi P, Leone N, Danese S, Montorsi M. Laparoscopic surgery for recurrent Crohn's disease. Gastroenterol Res Pract. 2012;2012:381017

7. Shore G, Gonzalez QH, Bondora A, Vickers SM. Laparoscopic vs. conventional ileocolectomy for primary Crohn disease. Arch Surg. 2003:138(1):76-9.

8. Soop M, Larson DW, Malireddy K, Cima RR, Young-Fadok TM, Dozois EJ. Safety, feasibility, and short-term outcomes of laparoscopically assisted primary ileocolic resection for Crohn's disease. Surg Endosc. 2009;23(8):1876-81.

9. Umanskiy K, Malhotra G, Chase A, Rubin MA, Hurst RD, Fichera A. Laparoscopic colectomy for Crohn's colitis. A large prospective comparative study. J Gastrointest Surg. 2010;14(4):658-63.

10. Kroesen AJ, Gröne J, Buhr HJ, Ritz JP. Therapy of refractory proctocolitis and Crohn's disease. Incisionless laparoscopic proctocolectomy with a Brooke ileostomy. Chirurg. 2009;80(8): 730-3. German

11. Bemelman WA, Slors JF, Dunker MS, van Hogezand RA, van Deventer SJ, Ringers J, et al. Laparoscopic-assisted vs. open ileocolic resection for Crohn's disease. A comparative study. Surg Endosc. 2000;14(8):721-5.

12. Wu JS, Bimlaaum EH, Kodner IJ, Fry RD, Read TE, Fleshman JW Laparoscopic-assisted ileocolic resections in patients with Crohn's disease: are abscesses, phlegmons, or recurrent disease contraindications? Surgery. 1997;122(4):682-8; discussion 688-9.

13. Patel SV, Patel SV, Ramagopalan SV, Ott MC. Laparoscopic surgery for Crohn's disease: a meta-analysis of perioperative complications and long term outcomes compared with open surgery. BMC Surg. 2013;13:14

14. Nguyen SQ, Teitelbaum E, Sabnis AA, Bonaccorso A, Tabrizian P, Salky B. Laparoscopic resection for Crohn's disease: an experience with 335 cases. Surg Endosc. 2009;23(10):2380-4.

15. Regan JP, Salky BA. Laparoscopic treatment of enteric fistulas. Surg Endosc. 2004;18(2):252-4. Epub 2003 Dec 29.

16. Schmidt CM, Talamini MA, Kaufman HS, Lilliemoe KD, Learn P, Bayless T. Laparoscopic surgery for Crohn's disease: reasons for conversion. Ann Surg. 2001;233(6):733-9.

17. Dignass A, Van Assche G, Lindsay JO, Lemann M, Soderholm J, Colombel JF et al. European Crohn's and Colitis Organisation (2010) The second European evidence-based Consensus on the diagnosis and management of Crohn's disease: current management. J Crohns Colitis. 2010;4(1):28-62.

18. Goyer P, Alves A, Bretagnol F, Bouhnik Y, Valleur P, Panis Y, Impact of complex Crohn's disease on the outcome of laparoscopic ileocecal resection: a comparative clinical study in 124 patients. Dis Colon Rectum. 2009;52(2):205-10.

19. Alves A, Panis Y, Bouhnik Y, Marceau C, Rouach Y, Lavergne-Slove A et al. Factors that predict conversion in 69 consecutive patients undergoing laparoscopic ileocecal resection for Crohn's disease: A prospective study. Dis Colon Rectum. 2005;48(12):2302-8.

20. Aarons CB. Laparoscopic surgery for crohn disease: a brief review of the literature. Clin Colon Rectal Surg. 2013;26(2):122-7.

21. Casillas S, Delaney CP. Laparoscopic surgery for inflammatory bowel disease. Dig Surg. 2005;22(3):135-42. 
22. Kristo I, Stift A, Argeny S, Mittlböck M, Riss S. Minimal-invasive approach for penetrating Crohn's disease is not associated with increased complications Surg Endosc. 2016;30(12): 5239-5244

23. Kessler H, Mudter J, Hohenberger W. Recent results of laparoscopic surgery in inflammatory bowel disease. World J Gastroenterol. 2011;17(9):1116-25.
24. Antoniou SA, Antoniou GA, Koch 00, Pointner R, Granderath FA. Granderath a. Is laparoscopic ileocecal resection a safe option for Crohn's disease? Best evidence topic. Int J Surg. 2014;12(5):22-5. Epub 2013 Nov 15

25. Dasari BV, McKay D, Gardiner K. Laparoscopic versus Open surgery for small bowel Crohn's disease. Cochrane Database Syst Rev. 2011;(1):CD006956. 